\title{
The Image of the United Kingdom in Chinese History Textbooks of the 1930-1940s
}

\author{
A. A. Dmitrenko \\ Heidelberg University, \\ 2, Voßstraße, Heidelberg, 69117, Germany
}

For citation: Dmitrenko A. A. The Image of the United Kingdom in Chinese History Textbooks of the 1930-1940s. Vestnik of Saint Petersburg University. Asian and African Studies, 2019, vol. 11, issue 2, pp. 252-261. https://doi.org/10.21638/spbu13.2019.209

The article represents an analysis of the image of the United Kingdom in Chinese textbooks of the 1930-1940s on the history of China and World history. A comparison of the image of the United Kingdom in Chinese history textbooks and World history textbooks will let us identify what kind of common image of this country was created in the minds of Chinese students of the 1930-1940s. The period covered in this paper includes the Nanking decade, when the Kuomindang implemented a more nationalist educational policy, and the period preceding the foundation of the PRC. There is a duality of the image of the United Kingdom in both the Chinese history textbooks and the World history textbooks. In the Chinese history textbooks the British are portrayed as quite "tenacious" people, who harbored hatred towards the Chinese because of their refusal to cooperate, and they are also portrayed as occupiers. On the other hand, the textbooks indicate, that the Chinese diplomatic policy was not always right and there were some domestic problems that contributed to development of conflicts, diplomatic defeats and lost of the wars. In the World history textbooks the United Kingdom is an imperialistic country; however, it is considered to be "the engine of progress", the creator of constitutionalism and an advocate of human rights. While describing the United Kingdom as a distinguished Western European state, the textbooks do not create a holistic image of a concrete state, but rather an image of an "imperialistic power", denouncing imperialism as a whole. Nevertheless, the authors indicate certain features that are typical of the United Kingdom, namely, the leading role in the process of globalization, in promotion of imperialism and technological and scientific progress. Having provided an overview of the Western countries the authors of the history textbooks primarly focus on China.

Keywords: educational policy in Republican China, history textbooks, the image of the United Kingdom, curriculum.

\section{Introduction}

Creating an image of a certain state is an important task for the authors of study materials. Certain image can change depending on the diplomatic relations between the two states at the time of the creation of the textbook, and depending on the educational

* The study was implemented as part of the Heidelberg University and St. Petersburg State University collaboration project "Chinese perceptions of Russia and the West during the $20^{\text {th }}$ century: changes, continuities and contingencies" supported by RFBR- DFG grant.

(C) Санкт-Петербургский государственный университет, 2019 
policy pursued by the state. Therefore, the analysis of these materials is so important for understanding what kind of the state image is formed in the minds of students, and how this image changes over time.

The problems of shaping the image of foreign states and national identity in Chinese history textbooks were addressed by various researchers, including Prof. G. Müller-Saini, Prof. N. A. Samoylov, P.I. Rysakova, E. Vickers, S. Corcuff. Prof. Müller-Saini has studied the portrayal and framing of such concepts, as "we" and "others" in Chinese textbooks in the XX century, as well as analyzed the image of Europe in modern Chinese textbooks [1]. Other important issues of education strategies analyzed by Prof. Müller-Saini are related to teaching methods [2], curricula development, and teaching world history in China [3]. Liu, Hung, Vickers [4] and S. Corcuff [5] studied identity issues in the curricula and textbooks of the Republic of China. Russian researcher N. A. Samoylov, together with Li Suian, examined the image of the USSR in Chinese textbooks of the 1950s [6], P.I. Rysakova studied the images of the USSR and Russia [7], as well as that of the October Revolution in modern Chinese textbooks [8].

Undoubtedly, the image of a certain state forms in the mind of a person not only on the basis of what he/ she read in history textbooks, but also on the basis of what he/ she learned from the textbooks on other subjects (such as geography, natural science, English, etc.), news, movie characters, fiction, etc. Nevertheless, this article is limited to the study of history textbooks, as one of the most significant resources.

The United Kingdom was chosen for the analysis as the Western state that played an outstanding and controversial role in the history of China, namely, the United Kingdom unleashed two Opium Wars (1839-1842; 1856-1860), as well as participated in other military conflicts with China. These military conflicts were preceded by unsuccessful attempts to succeed in signing a treaty of commerce. The most famous embassy of Lord G. Macartney (1793) failed to achieve trade rights with China, which is regarded by the authors of textbooks as one of the reasons for launching the Opium War. At the same time, the United Kingdom played an important role in the international arena in the $19^{\text {th }}$ $20^{\text {th }}$ centuries. All this makes the United Kingdom the most prominent representative of the Western state in Chinese history textbooks.

Comparison of the image of the United Kingdom in textbooks on Chinese and world history allows us to find out its common (unified) image that was formed in the minds of Chinese students in the 1930s-1940s.

The period covered in this paper includes the Nanking decade (1927-1937), and the period preceding the foundation of the PRC in 1949. The Kuomintang party (the Nationalist party of China) accessing to power in 1927-1928, carried out a more nationalistic educational policy. Nationalism and patriotism were not a new ideology for Chinese intellectuals of the 1930s; nevertheless, an education reform took place in those years and during that period the state was able to assert a greater control over publishing houses and restricted considerably the independence of private schools [9, p. 25-28; 10, p. 144-172]. The year 1931 can stand as a certain benchmark when the Nationalist Government requested the League of Nations to prepare a plan for comprehensive education reform [11, p. 37-45]. During the Sino-Japanese War (1937-1945) and in the subsequent period prior to the establishment of the PRC, the Kuomintang, undoubtedly, did not exercise total control over a large part of the country, but not as much attention was paid to education during the wartime in general. Textbooks and curricula were barely altered during these 
turbulent years [12, p. 71]; hence, the textbooks produced at that time will be considered as part and product of preceding reforms.

The methodology used in this study relies on the methods specified in the UNESCO Guidebook on Textbook Research. This includes a comprehensive analysis of the content, vertical analysis, that helps to investigate how the presentation of a topic has changed over time, as well as qualitative and linguistic methods that provide answers to the questions: What is the general message of the text? In what context are terms placed? Is the text emotionally loaded? Are the protagonists considered as "victims" or "perpetrators"? [13, p. 30-32, 68-71].

The term “England” (英國) is used throughout the textbooks; nonetheless, we use the term "United Kingdom" in this paper, because we mostly discuss the events that took place in the XIX century and later, in this regards, referring to England exclusively would not be fully appropriate in this context. However, when speaking of the events dating back to the XIII century, the term "England" is used, because the United Kingdom did not exist at that time. The textbooks, in turn, while describing the events of the XIX century refer to the United Kingdom as 英國 or 英.

The Collected twentieth-century curriculum standards and teaching outlines can be regarded as the supporting material for the study of the image of foreign states in Chinese history textbooks [14]. Although this resource provides only an insight into the general goals pursued by textbook compilers, it is important for understanding the authors' ideology and what they intended to put into the minds of students. Interestingly enough, the curricular goals for 1932 and 1936 are identical; so we cannot speak of any fundamental changes in textbooks throughout the 1930s. The objectives for 1940 and 1941 are also similar and do not differ much from those indicated in the curricula for the 1930s [14, p. 43-88].

While talking about the image of the United Kingdom one should pay attention to the following goals indicated in the curricula for 1932, 1936:

1. Curriculum for junior high school: "To study the development of Chinese people (中國民族); especially describe (explain 說明) its historical glory and the modern invasion of the Great Powers and the reasons for this process, in order to inspire the students for the national revival, cultivate self-confidence and consciousness in them, and cultivate their desire to develop"; "to provide an overview of the history of each and every state, describe their cultural features, in order to give students a general knowledge of the world, pay special attention to the causes of the current situation in international relations and China's place in them, in order to raise in students the sense of responsibility for national movements in the country" [14, p. 43];

2. Curriculum for senior high school: "To pay due attention to the history of failure in current (as of that time - A. D.) diplomacy and the origin of modern political and economic problems, in order to explain the background of the national revolution, to indicate that in the future the people of the state must be zealous"; "To describe the development of every important (!) nation and changes in culture, politics and society of every state"; "To describe the development of modern imperialism, the general status of national movements and the origin of important contemporary international problems" [14, p. 50]. 
As can be seen already from these curricula excerpts, commissions have set the goal to raise students in patriotism, to cultivate self-confidence and teach them to take pride in their nation, to give a general knowledge of the states and nations, which in their view are important, to highlight the history of national movements, and show the importance of the fight for independence. It should be noted that throughout the textbooks one can sense a negative attitude towards monarchy and imperialism on the one hand, and praise for revolutions and liberal movements on the other.

In the case of the United Kingdom, we can see two "images": on the one hand, the image of the United Kingdom in Chinese history (which is mostly negative), on the other hand, the image of the United Kingdom in world history, where the British are portrayed not only as the imperialists but also act as the authors of such concepts as human rights and constitution, creators of the industrial revolution, and proponents of development of science and progress. At the same time, the authors strive to demonstrate the contribution of the Chinese nation to the development of modern science", mention " 3 great inventions of China" - gunpowder, printing press ${ }^{2}$, and compass ${ }^{3}$.

The British come as part of the common image of the Western Great Powers and nations, which are generally shown as ambitious, cunning and $\mathrm{cruel}^{4}$, who came to China with their ambitions, mainly for the extraction of resources, for trade and Christian preaching. Nonetheless, as stated in the textbook for higher primary school of 1948, the main purpose of Europeans was a trade, while Christian preaching and the "Western learning" (西學) came next in importance [18, p. 5].

Certainly, the British actions towards China in the $19^{\text {th }}-$ early $20^{\text {th }}$ centuries can hardly be interpreted as positive by Chinese authors, the only question is what kind of words are used to describe the Europeans and the British in particular? What do the au-

1 This objective is also indicated in the curriculum for 1932, junior high school: "to explain, what was the contribution of Chinese culture to world culture, so that students are aware of the great deeds of our ancestors, in order to develop noble aspirations and self-improvement spirit in them". See: [14, p. 43]. The goals for the senior high school curriculum indicate that "the above-mentioned goals complement the goals specified in the junior high school curriculum". The goals for the senior high school contain a similar item: "to show the contribution of every nation to the world culture". See: [14, p.50].

2 As regards the printing press (printing technique), it is said that this invention came to Europe from China and made a great contribution to the dissemination of culture [15, p. 22]; however, no direct influence of Chinese printing technique on the invention of printing press by Gutenberg can be attested and, according to M. Breede, most of the researchers believe that Gutenberg's printing press is an independent invention, free of the influence of Chinese inventors [16, p.33].

3 According to the author of one of the textbooks, the Europeans admired Chinese culture, and after discovering these " 3 Chinese treasures", the Europeans desired to bring the Chinese their greatest learning/ science (學術) - Christianity. See: [17, p.36]. The compass is repeatedly referred to as the Chinese invention, which gave a huge impetus to the development of the shipping industry and, accordingly, the discovery of new lands [15, p. 22, 23]. The textbook published in 1948 says that the Europeans used the "compass that came from China and the knowledge of geography that came to them from the Arab Empire, and thus maritime navigation developed". See: [18, p. 1].

${ }^{4}$ For instance, according to Chinese historiography, the Portuguese got the territory of Macao and opened a port there by bribing a local official, Huang Qing, and then suddenly (!) declared Macao their territory. The Portuguese told Chinese officials that the gifts for the Emperor got wet and asked for more land to dry them up. The official gave them land, so the Portuguese obtained even more territory. Later they asked to reduce the land tax and the government could do nothing but reduce the tax to 500 Liang. Realizing that the Chinese are so easy-going/careless (随便), the Europeans desired to fulfill their ambitions - to occupy China. At the same time, Spanish, Dutch, and British merchants also came to China. See: [17, p. 34, $35 ; 19$, p. $2 ; 20$, p. 2$]$. 
thors focus on? How they interpret certain facts? Do they mention facts or create a generally negative image of the Europeans? Do the authors focus on evoking certain emotions in students, in other words, what is the emotional coloring of the narration?

\section{The image of the United Kingdom in the textbooks on Chinese history}

First, it should be noted that the United Kingdom is shown as the state that entered into a rivalry with other European countries for the rights to trade with China.

The authors of textbooks repeatedly mention that initially, Portugal ${ }^{5}$ and Spain ${ }^{6}$ had almost monopoly rights on trade with China, while other states could not gain the same rights [20, p. 1; 23, p. 204]. The United Kingdom stands out among other representatives of the "Western imperialism" because of two Opium Wars and the backstory of attempts to sign trade treaties with China. The failure to gain trade rights is indicated as the trigger of the Opium War: since China refused to sign the commercial treaty, British traders lost hope (大失所望). The British “harbored hatred (心懷 怨恨) [towards the Chinese]” or "hated China bitterly (颇恨中國)" [22, p. 62], and as soon as the ban on the opium trade was issued, they sent troops to attack China [18, p. 23; 22, p. 62; 24, p. 23]. Here, one can see a powerful emotional coloring of the British as those who harbored hatred towards the Chinese because of their refusal to cooperate.

One of the textbooks also mentions the refusal to trade as the reason for the outbreak of war, but it is also indicated that the British had a "strong will" (銳意) to forge an agreement with the Chinese and sign commercial treaties, so they negotiated again and again. After much persuasion, the Kangxi Emperor (1654-1722) agreed to open a trade port in Guangzhou. However, taxes on the port trade increased later. According to the author, the remote cause of the Opium War was the ceremonial requirement, namely, the British envoy George Macartney (1737-1806) was requested to perform a kowtow before the Emperor (something he "could not afford") [19, p. 30, 31]. Judging by the questions for reflection, "What was the attitude of the Qing government towards trading with the United Kingdom? What was the attitude towards the British envoys? Is this diplomatic policy correct? [19, p. 33]", the authors imply that such policy was wrong and part of the responsibility for the conflict with the United Kingdom rests with the Qing government.

Describing the situation in the country before the Opium War, the authors point to the state problems caused by the Emperor's policy and the immorality of officials: the Emperor Qianlong (1711-1799) “craved for greatness and success" (好大喜功), traveled a lot (樂 巡游), wasted public funds (虛耗國帑). Such policies led to the waste of human and material resources (勞民傷財). The Manchu official Heshen (1746-1799) openly raked in money and took/offered bribes (斂財納賄) [19, p. 31].

It is often mentioned that the demands of the Great Powers' to divide China were heard in the country and beyond. The textbook edited by Chu Hui, for instance, indicates that the Great Powers not only occupied the territories but also forced (壓迫) China to permit railway construction, mine valuable minerals, meaning both military and eco-

${ }^{5}$ Nevertheless, sometimes it is said that only Portugal enjoyed trading rights because the Netherlands traded with the Chinese in Taiwan, Spain — in the Philippines. See: [21, p. 53].

${ }^{6}$ In one of the textbooks, the author acknowledges that in those times (the $16^{\text {th }}$ century), the Chinese did not distinguish the Spaniards and the Portuguese, and called them Folanji. The footnote states that the name came from the Arabs who called the Western Europeans the "Folan" [22, p. 4, 5, 11]. 
nomic occupation. However, in the next chapter entitled "seedlings of the revolution", the author indicates that the situation in which China was at that time caused protests of the local population, which triggered revolutionary actions against the Manchu government (當時的國人，受了這樣的刺激，怎樣會的不警奮起來) [25, p. 14].

Notably, some authors mention that the Chinese treated the Europeans as barbarians, felt superior and did not bother to learn their culture, had some false perceptions, all that sometimes led to conflicts $[18$, p. $25 ; 23$, p. 205,206$]$. They also indicate the problems in the Qing empire since the late XVIII century, such as corruption, bureaucracy, weak army, low level of education, etc [23, p. 212, 213].

The description of the Boxer Rebellion (Yihetuan movement) (1899-1901) is particularly emotional: following numerous defeats in wars and signing "unequal treaties" China permitted the Europeans to establish consulates, to open companies, to preach. Upon receiving these rights, the foreigners committed any kind of crimes (什麼壞事 都 做了出來) and hid in foreign settlements at the earliest opportunity. Missionaries humiliated and ridiculed the Chinese everywhere; while talking about humanity, they themselves committed any imaginable misdeeds (無惡不作 “there was no such evil that they would not have done") [18, p. 39, 40; 25, p. 17]. The Boxers (Yihetuan) are shown as bold (毫無 畏懼 “absolutely fearless”) and faithful (前仆後繼 “one falls, the next follows”) fighters, while the actions of joint forces are not viewed as heroic. When they intruded Beijing, they killed and plundered, "making thousand-year-old jewels their souvenirs" $[25$, p. 18,19$]$. It should be mentioned here that the authors speak first and foremost of foreigners in general and missionaries, without specifying their national identity. Nonetheless, regardless of the national background of the missionaries and Christians, their actions (and of those who adopted Christianity for some "privileges" or "advocacy") and the "protectorate" of the Great Powers (thanks to which they could commit "any imaginable misdeeds") were the causes of hatred towards them.

The United Kingdom is mentioned in the history of China in the context of the following events: the first contacts and diplomatic relations with the West/ Europe (Western power / European presence in China / in the East 歐洲勢力 來華 / 海外勢力的侵入 / 歐 勢東漸); the Opium Wars 1 and 2, “Unequal Treaties” (Nanking (1842), Tientsin (1858), Convention of Peking (1860)); the Yihetuan movement. Despite the fact that some authors point to misperceptions of the Europeans by the Chinese, recognize that they were viewed as barbarians, and acknowledge China's internal problems, the image of the United Kingdom in Chinese history, in general, can be seen as negative. The authors of textbooks note that the Western powers were "tenacious", aggressive, sometimes cheated, though in some cases the authors do not view the objectives of some Western Powers as negative (for example, the desire of the United Kingdom to trade with China), but condemn the way these objectives were achieved. In contrast, the Chinese government is often depicted as the government, which is ready to concede or compromise. Nonetheless, the actions of the Emperor or officials in diplomacy and domestic policy are sometimes criticized.

7 According to the definition given in the textbook published in 1948 regarding the Treaty of Nanking, this treaty is unequal, because the United Kingdom gained rights in China, while China gained no rights in the United Kingdom [18, p. 23, 24]. 


\section{The image of the United Kingdom in world history textbooks}

As noted earlier, the image of the United Kingdom in world history textbooks is not so unambiguous: on the one hand, the United Kingdom is the proponent and author of the Constitution, an advocate of human rights and creator of the industrial revolution, on the other hand - an imperialist and colonizing state.

As stated in one of the textbooks, already in the XIII century, England laid the foundations of constitutionalism, in particular, the "Magna Carta Libertatum" is referred to as "the starting point (foundation) of constitutions of all countries in the whole world" [18, p. 10;26, p. 14-16]. The authors praise the industrial revolution that came from the United Kingdom and has changed the entire world. Its influence is seen in two aspects: 1. Development of material culture (物質文明 大為 進步); 2. Improvement in the quality of life (人類的生活也日見改善) [18, p. 17, 18]. At the same time, the industrial revolution is viewed as something that led to improving the standard of living and the development of science, and on the other hand, it contributed to the development of imperialism and colonial expansion.

When describing the development of science and history of ideas the textbooks mention such English philosophers as Roger Bacon (1214-1292) and Francis Bacon (1561-1626), the physicist and chemist John Dalton (1766-1844) and his atomic theory. Observation and experiment as the main research methods are contrasted with conservatism and implicit faith in what is said in the books. The authors pay special attention to Darwin's theory of evolution, adding that "after the evolutionary theory was developed, the statement that everything had been created by God was rejected and human thought could develop freely" [18, p. 21].

Pointing to the negative aspect of the industrial revolution, the author of one of the textbooks express a somewhat utopian idea of assistance to "small nations". Assistance had to be provided by the Great Powers while extracting minerals in other countries. The textbook reads: "However, they did not act upon the principle of mutual assistance to help small nations develop but used the method of occupation to suppress them" (但 是他們不採取人類以互助求進化的原則來幫助弱小民族，而採取侵略的方式來壓 迫他們) and this struggle for resources led to wars [18, p. 19] ${ }^{8}$. It should be noted that chapters dedicated to such large wars as the First Opium War [26, p. 31; 18, p. 22] or the First World War [15, p. 45] usually follow the description of the industrial revolution and its influence.

In general, it can be stated that the textbooks display a certain duality in evaluating the activities of the United Kingdom, both in Chinese history and in world history. In Chinese history, the British were "tenacious", harbored hatred for refusing to cooperate, and are described as invaders. On the other hand, the general diplomatic policy of China was also not always correct; the existing domestic problems contributed to conflicts and defeats in both diplomacy and wars. At the same time, China is shown as a kind of "victim" of the imperialist powers. Several aspects indicate that: the defeats in the Opium Wars, the term "unequal treaties" introduced in traditional Chinese historiography, the claims of the Great Powers to divide China, and finally the Boxer rebellion, where the Boxers are

${ }^{8}$ Other textbooks also indicate that the industrial revolution led to the struggle for resources and colonial expansion in Asia and Africa. See: [26, p. 29-31; 15, p. 38-44]. 
described as courageous and faithful sons of the homeland rebelling against the arbitrary actions of the imperialist states.

\section{Consclusion}

In the world history textbooks, the United Kingdom is, on the one hand, an imperialist state; on the other hand, it is the engine of progress, creator of the constitution and an advocate of human rights. We should keep in mind that the textbooks consider certain ideas or phenomena either as positive or negative. The positive phenomena include the following: freedom of thought, lack of religious prejudice, the movement for independence, the development of science. The following phenomena are blamed in turn: monarchy, imperialism, colonization, religious prejudices (unscientific approach). Consequently, the image of a state may vary depending on what phenomena are observed in a particular state.

As can be seen, the content of textbooks is fully consistent with the goals specified in the collection of curriculum standards. However, while distinguishing the United Kingdom from other Western powers the textbooks not so much create a holistic image of a certain state (in this case, the image of the United Kingdom), as the image of an "imperialist state", denouncing imperialism (as a whole) and the Great Powers' intrusion into China, emphasizing the importance of anti-monarchy movements for liberalism and independence. Nevertheless, the authors note some features peculiar to the United Kingdom, namely, its leading role in the globalization process, in the promotion of imperialism and technological and scientific progress. Having provided an overview of the Western countries the authors of the history textbooks primarily focus on China, its history, contribution to the world culture and its place in the international arena.

\section{References}

1. Müller Gotelind. Teaching 'the others' history' in Chinese schools: the state, cultural asymmetries and shifting images of Europe (from 1900 to today). Designing History in East Asian Textbooks. Identity Politics and Transnational Aspirations. London, New York, Routledge, Routledge Studies in Education and Society in Asia, 2011, pp. 32-59.

2. Müller Gotelind. How to tell my child? Strategies used in current Chinese school textbooks to transmit the normative view on history [2008]. Heidelberg, Universitätsbibliothek Heidelberg, 2013. 26 p.

3. Müller Gotelind. World history education in the PRC between textbooks and television: some observations on recent developments. Li Xiangyu (ed.). Tian ren gu jin: Huaren shehui lishi jiaoyu de shiming yu tiaozhan [Nature and man, past and present: the mission and challenges of socio-historical education among Chinese]. Macau, Aomen ligong xueyuan, 2014, pp. 8-22.

4. Liu Mei-hui, Hung Li-ching, Vickers Edward. Identity Issues in Taiwan's History Curriculum. Edward Vickers, Alisa Jones (eds). History Education and National Identity in East Asia. New York, London, Routledge, Taylor and Francis Group, 2005, pp. 101-131.

5. Corcuff S. History Textbooks, Identity Politics, and Ethnik Introspection in Taiwan: The June 1997 Knowing Taiwan Textbook Controversy and the Questions It Raised on the Various Approaches to "Han" Identity. Eds E. Vickers, A. Jones. History Education and National Identity in East Asia. New York, London, Routledge, Taylor and Francis Group, 2005, pp. 133-169.

6. Samoylov N. A., Li Suian. Obraz Sovetskogo Soiuza v kitaiskikh uchebnikakh 1950-kh godov [Image of the Soviet Union in the Chinese textbooks in 1950s]. Vestnik Sankt-Peterburgskogo universiteta. Series 13, 2012, no. 4, pp. 14-22. (In Russian) 
7. Rysakova P. I. The Image of the Soviet Union and Russia in Chinese history textbooks of the 2000s (in the perspective of development of Chinese historiography). Vestnik of Saint Petersburg University. Asian and African Studies, 2017, vol. 9, issue 4, pp. 457-468. (In Russian)

8. Rysakova P. I., Dmitrenko A. A., Bogomazov N. I. Obraz Oktiabr'skoi revoliutsii v rossiiskikh i kitaiskikh shkol'nykh uchebnikakh dlia srednei shkoly 2000-kh gg. [The Image of the October revolution in Russian and Chinese History Textbooks of the 2000s]. Noveishaia istoriia Rossii [Modern History of Russia], 2018, vol. 8, no. 1, pp. 208-217. (In Russian)

9. Zarrow P. Educating China: knowledge, society and textbooks in a modernizing world, 19021937. Cambridge, Cambridge University Press, 2015. 284 p.

10. Helen R. Chauncey. Schoolhouse Politicians: Locality and State During the Chinese Republic. Honolulu, University of Hawaii Press, 1992. 300 p.

11. Pepper S. Radicalism and Education Reform in 20th-century China: The search for ideal development model. Cambridge, Cambridge University Press, 1996. 610 p.

12. Jones A. Changing the Past to Serve the Present: History Education in Mainland China. Eds E. Vickers, A. Jones. History Education and National Identity in East Asia. New York, London, Routledge, Taylor and Francis Group, 2005, pp. 65-100.

13. Pingel F. UNESCO Guidebook on Textbook Research and Textbook Revision. $2^{\text {nd }}$ ed. Paris, Braunschweig, United Nations Educational, Scientific and Cultural Organization, 2010. 83 p.

14. Kecheng jiaocai yanjiusuo [Institute for Curricular Teaching Materials] (comp.) 20 shiji Zhongguo zhongxiaoxue kecheng biaozhong - jiaoxue dagang huibian. Lishijuan. [Collected twentieth century curriculum standards and teaching outlines for Chinese secondary and primary school: history]. Beijing, Renmin jiaoyu, 2001. 755 p. (In Chinese)

15. Chu Hui, ed. Beixin lishi jiaoben - Gaoji jiaoxueyong [Higher senior primary school history textbook]. Vol. 4. Shanghai, Beixin shuju, 1932. 70 p. (In Chinese)

16. Breede M. The Brave New World of Publishing: The symbiotic relationship between printing and book publishing. Oxford, Chandos Publishing, 2008. 193 p.

17. Chu Hui, ed. Beixin lishi jiaoben - Gaoji jiaoxueyong [Higher senior primary school history textbook]. Vol. 2. Shanghai, Beixin shuju,1932. 46 p. (In Chinese)

18. Gaoji xiaoxue lishi keben [Higher primary school history textbook]. Vol.3. Shanghai, Shangwuyin shuguan, 1948. 50 p. (In Chinese)

19. Chuzhong benguoshi [Junior middle school China's history textbook]. Vol.3. Beijing, Xinminyin shuguan, 1939. 110 p. (In Chinese)

20. Chuzhong benguoshi [Junior middle school China's history textbook]. Vol.3. Beijing, Xinminyin shuguan, 1942. 110 p. (In Chinese)

21. Chuzhong benguo lishi jiaoben [Junior middle school China's history textbook]. Vol.3. Shanghai, Shanghai dadong shuju yinxing, 1932. 116 p. Reprinted in 1933. (In Chinese)

22. Ying Gongjiu, ed. Chuzhong benguoshi [Junior middle school China's history textbook]. Vol. 3. Nanjing, Zhengzhong shuju, 1936. 158 p. (In Chinese)

23. Chen Dengyuan, ed. Chenshi gaozhong benguoshi [Senior high school China's history textbook]. Vol.2. Shanghai, Shijie shuju, 1935. 338 p. (In Chinese)

24. Gaoji xiaoxue lishi keben [Higher primary school history textbook]. Vol.3. Shanghai, Shangwuyin shuguan, 1947. 50 p. (In Chinese)

25. Chu Hui, ed. Beixin lishi jiaoben - Gaoji jiaoxueyong [Higher senior primary school history textbook]. Vol.3. Shanghai, Beixin shuju,1932. 51 p. (In Chinese)

26. Gaoxiao lishi [Higher primary school history textbook]. Vol.3. Beijing, Zhongguo lianhe chuban gongsi, 1944. 47 p. (In Chinese)

Received: October 1, 2018

Accepted: March 26, 2019

Author information:

Aleksandrs A.Dmitrenko — PhD, Research Associate; aleksandrs.dmitrenko@zo.uni-heidelberg.de 


\section{Образ Великобритании в китайских школьных учебниках 1930-1940-х годов ${ }^{\star}$}

\section{А. А. Дмитренко}

Гейдельбергский университет им. Рупрехта и Карла, Германия, 69117, Гейдельберг, ул. Фосс, 2

Для цитирования: Dmitrenko A. A. The Image of the United Kingdom in Chinese History Textbooks of the 1930-1940s // Вестник Санкт-Петербургского университета. Востоковедение и африканистика. 2019. Т. 11. Вып. 2. С. 252-261. https://doi.org/10.21638/spbu13.2019.209 (In English)

Статья посвящена анализу образа Великобритании в китайских учебниках по истории мира и Китая 1930-1940-х годов. Сравнение образов Великобритании в учебниках истории Китая и мира позволит понять, какой общий образ данного государства формировался в сознании китайских учеников в 30-40-х гг. ХХ столетия. Рассматриваемый период охватывает нанкинское десятилетие, когда Гоминьдан стал проводить более националистическую политику в сфере образования, и последующий период до образования КНР. Как в учебниках по истории Китая, так и в учебниках по мировой истории присутствует двойственный образ Великобритании. В истории Китая британцы действовали «напористо», затаили ненависть за отказ идти на сотрудничество, а также описываются как оккупанты, с другой стороны, согласно учебникам, и с китайской стороны общая дипломатическая политика не всегда была верна, присутствовали внутригосударственные проблемы, которые способствовали конфликтам, проигрышу как в дипломатии, так и в начавшихся войнах. В учебниках по мировой истории Великобритания, с одной стороны, является империалистическим государством, с другой - двигателем прогресса, создателем конституции и борцом за права человека. Выделяя Великобританию из других западных держав, учебники тем не менее создают не столько цельный образ конкретного государства, сколько образ «империалистического государства», осуждая империализм в целом. Впрочем, авторы отмечают и некоторые черты, характерные именно для Великобритании, а именно важнейшую роль в процессе глобализации, продвижении империализма и технологического и научного прогресса. Давая общее представление о западных государствах, авторы учебников прежде всего говорят о Китае и его месте на международной арене.

Ключевые слова: образовательная политика Республиканского Китая, исторические учебники, образ Великобритании, учебный план.

Статья поступила в редакцию 1 октября 2018 г., рекомендована к печати 26 марта 2019 г.

Контактная информация:

Дмитренко Александр Анатольевич - PhD, науч. сотр.;

aleksandrs.dmitrenko@zo.uni-heidelberg.de

* Исследование выполнено в рамках совместного проекта ученых Гейдельбергского университета и СПбГу “Chinese perceptions of Russia and the West during the $20^{\text {th }}$ century: changes, continuities and contingencies”, поддержанного грантом РФФИ и DFG. 